\title{
Sex Guilt or Sanctification? The Indirect Role of Religiosity on Sexual Satisfaction
}

\author{
Nathan D. Leonhardt \\ University of Toronto \\ Dean M. Busby \\ Brigham Young University - Provo, dean_busby@byu.edu \\ Brian J. Willoughby \\ Brigham Young University - Provo
}

Follow this and additional works at: https://scholarsarchive.byu.edu/facpub

Part of the Other Social and Behavioral Sciences Commons

\section{Original Publication Citation}

Leonhardt, N. D., Busby, D. M., \& Willoughby, B. J. (2020). Sex guilt or sanctification? The indirect role of religiosity on sexual satisfaction. Psychology of Religion and Spirituality, 12, 213-222.

\section{BYU ScholarsArchive Citation}

Leonhardt, Nathan D.; Busby, Dean M.; and Willoughby, Brian J., "Sex Guilt or Sanctification? The Indirect Role of Religiosity on Sexual Satisfaction" (2019). Faculty Publications. 4639.

https://scholarsarchive.byu.edu/facpub/4639

This Peer-Reviewed Article is brought to you for free and open access by BYU ScholarsArchive. It has been accepted for inclusion in Faculty Publications by an authorized administrator of BYU ScholarsArchive. For more information, please contact ellen_amatangelo@byu.edu. 


\title{
Sex Guilt or Sanctification? The Indirect Role of Religiosity on Sexual Satisfaction
}

\author{
Nathan D. Leonhardt \\ University of Toronto
}

\author{
Dean M. Busby and Brian J. Willoughby \\ Brigham Young University
}

\begin{abstract}
With a Mechanical Turk sample of 1,614 sexually active individuals $(62.6 \%$ women, $85 \%$ heterosexual, mean age of 34.47 years) who had been in a committed sexual relationship for at least two years, we used structural equation modeling to better understand how global religiosity may indirectly influence sexual satisfaction. Because religiosity has been linked to the way people make sense of sexuality, we assessed positive (sexual sanctification) and negative (sexual guilt) meaning making variables as mediators between religiosity and sexual satisfaction. Consistent with prior research, greater sanctification of sexuality was directly tied to greater sexual satisfaction, whereas greater sexual guilt was directly tied to less sexual satisfaction. Greater general religiosity was indirectly related to greater sexual satisfaction for men and women through greater sexual sanctification. Contrary to expectations, no significant pathways emerged between greater religiosity and less sexual satisfaction via sexual guilt, possibly due to reliance on a one item indicator for the latter variable. Also, in structural equation models, when sanctification of sexuality was taken into account, greater religiosity was directly tied to less sexual satisfaction for women, but not for men. This suggests that sanctification of sexuality represents a facet of religiousness that facilitates women's and men's sexual satisfaction, whereas other religious beliefs may inhibit women's sexual satisfaction.
\end{abstract}

Keywords: religiosity, sexual sanctification, sexual guilt, sexual satisfaction

Religion brings potential for joy, pain, healing, hurt, esteem, shame, love, and hate (Dollahite, Marks, \& Dalton, 2018). These paradoxical dualities (i.e., opposites or contrasts) have been well documented in general psychology of religion and spirituality (Pargament, 1997) and specifically in couple relationships (Mahoney, 2010; Mahoney, Pargament, Tarakeshwar, \& Swank, 2001). Notably, different facets of religiosity have been linked to relationships of gender inequality (e.g., Bartkowski, 2001; Sigalow \& Fox, 2014) and spousal abuse (e.g., Simonic, Mandelj, \& Novsak, 2013; Stotland, 2000), while also being connected to relationships with high satisfaction (e.g., Fincham, Beach, Lambert, Stillman, \& Braithwaite, 2008; Olson, Marshall, Goddard, \& Schramm, 2015) and commitment (e.g., Fincham \& Beach, 2014; Lambert \& Dollahite, 2008). Sexuality is one aspect of a couple's relationship where some researchers have suggested the importance of considering dualities (Christopher \& Sprecher, 2000; Hernandez, Mahoney, \& Pargament, 2014; Murray-Swank, Pargament, \& Mahoney, 2005), as scholars have found positive (Hardy \& Willoughby, 2017; Murray-Swank et al., 2005) and negative

This article was published Online First January 7, 2019.

Nathan D. Leonhardt, Department of Psychology, University of Toronto; Dean M. Busby and Brian J. Willoughby, School of Family Life, Brigham Young University.

Correspondence concerning this article should be addressed to Nathan D. Leonhardt, Department of Psychology, University of Toronto, 3359 Mississauga Road, Toronto, ON L5L1C6, Canada. E-mail: nathan .leonhardt@mail.utoronto.ca associations (Davidson, Moore, \& Ullstrup, 2004) as well as the absence of an association (Ashdown, Hackathorn, \& Clark, 2011; Young, Denny, Luquis, \& Young, 1998) between indicators of religiosity and sexual satisfaction.

A dualistic perspective (a long-held approach recently highlighted in a synthesis; Dollahite et al., 2018) may clarify inconsistent findings between global religiosity (i.e., overall religious devotion) and sexual satisfaction, as a number of mechanisms may explain how religiosity could both negatively and positively influence sexual satisfaction. Recently, scholars have suggested that the inconsistent link may be due to neglecting explanatory variables between religiosity and sexual satisfaction. Rather than having a direct link, religiosity may indirectly influence sexual satisfaction by informing sexual meaning or attitudes (e.g., Hackathorn, Ashdown, \& Rife, 2016; Hardy \& Willoughby, 2017). Consistent with the suggestion of religious dualities, religiosity has been linked to both positive and negative sexual meaning constructs. On the negative, religiosity has been linked to overall heightened sexual concerns and discomfort (Cowden \& Bradshaw, 2007), particularly to sexual guilt (i.e., a negative affective component, comprised of self-imposed punishment for either violating or expecting to violate "proper" sexual conduct; Hackathorn et al., 2016; Woo, Brotto, \& Gorzalka, 2011). In turn, sexual guilt has been linked to lower sexual satisfaction (Hackathorn et al., 2016; Higgins, Trussell, Moore, \& Davidson, 2010). Conversely, religiosity has also been linked to a positive valuation of sexuality (Hardy \& Willoughby, 2017; Hernandez, Mahoney, \& Pargament, 2011; Hernandez-Kane \& Mahoney, 2018), specifically to sexual sanctification (i.e., believing sexuality to have divine character and 
significance; Hernandez et al., 2011). Sexual sanctification in turn has been positively linked to sexual satisfaction (Hernandez et al., 2011; Hernandez-Kane \& Mahoney, 2018). We suggest that by simultaneously considering how religiosity may indirectly influence sexual satisfaction through both a negative valuation (sexual guilt) and a positive valuation (sexual sanctification), we can begin to better understand previous conflicting findings.

In this study, using a sample of 1,614 adults in committed sexual relationships, we explored the extent that religiosity indirectly influences sexual satisfaction through sexual guilt and sexual sanctification. By including both negative and positive valuations of sexuality, we hoped to provide an initial inquiry into the dualities between religiosity and sexual satisfaction with a large scale, quantitative analysis.

\section{Sexual Guilt}

With some religious assertions of sexuality throughout history being connected to original sin, a barrier to be overcome, an open sore that must be scratched, and a natural depravity of the human body (Boulder, 1998; Schnarch, 1991), it seems plausible that some religious individuals could have discomfort and conflict surrounding sexuality. Freud (1927/1961) was among the earliest in the social sciences to note a precarious relationship between religiosity and sexuality, commenting on how pessimistic and inhibitory emphasis in religion has been used to regulate sexual conduct, an idea that now has empirical validation (e.g., Buss, 2002). This negatively imbued, highly regulated outlook on sexuality appears to be one reason that religiosity has been consistently connected to an overall uneasiness surrounding sexuality, particularly sexual guilt (e.g., Emmers-Sommer, Allen, Schoenbauer, \& Burrell, 2018; Murray, Ciarrocchi, \& Murray-Swank, 2007; Woo, Morshedian, Brotto, \& Gorzalka, 2012). Logically, viewing sexuality as something inherently dirty, debased, or a necessary evil for procreation could result in feelings of moral disapprobation when participating in a sexual act. Little research has directly analyzed the negative connection between sexual guilt and sexual satisfaction (for exceptions, see Hackathorn et al., 2016; Higgins et al., 2010). However, many other studies indirectly suggest a negative connection, as a recent meta-analysis found that sexual guilt was linked to lower sexual activity, less sex information accuracy, and less positive attitudes toward sex (Emmers-Sommer et al., 2018).

Religiosity appears to be connected to sexual guilt for unmarried individuals (Hackathorn et al., 2016), as most religious teachings are particularly restrictive of sexual behavior outside of a heterosexual marriage (Delamater, 1981; Miracle, Miracle, \& Baumeister, 2003). However, few research findings exist on religiosity and sexual guilt for couples within a committed or married relationship. Those that do exist present a somewhat inconsistent picture. Considering that many religions fully sanction sexuality within a marital relationship (Hernandez et al., 2014), some have suggested that sexual guilt may be unlikely to exist for religious individuals who channel their sexuality into a God sanctioned marriage (Dollahite, Marks, \& Goodman, 2004). However, some studies have shown that sexual guilt continues to pervade religious, married individuals (Peterson, 1964), as some scholars have suggested that religiosity can bring a more permanent sense of anxiety, guilt, and tension surrounding sexuality (Runkel, 1998). This is perhaps due to some religious teachings condemning any sexual activity only for pleasure, rather than for procreation (Abbott, Harris, \& Mollen, 2016; Cowden \& Bradshaw, 2007). Therefore, research suggests that religiosity could negatively influence sexual satisfaction by imbuing the sexual relationship with sexual guilt, though the role of marital status remains a matter of inquiry for this connection.

\section{Sexual Sanctification}

Although some scholars have begun to question whether Western culture's religious roots have led to an exclusively negative view of sexuality, others suggest religiosity has the potential to also imbue sexuality with positive meaning (Hernandez et al., 2014). Some Western religious teachings have sanctioned sexuality not only for its procreative potential to be cocreators with God, but also for bonding, pleasure, and enhancing a committed couple's union with each other and God (Hernandez et al., 2014; Lauer, 1985; Turner, Fox, \& Kiser, 2007).

Sanctification could be one specific positive meaning making process that could help religious individuals have a better sexual relationship. The concept of sanctification has received ample theoretical and empirical consideration for the sanctification of marriage (e.g., Ellison, Henderson, Glenn, \& Harkrider, 2011; Kusner, Mahoney, Pargament, \& Demaris, 2014) or a romantic relationship (Fincham, Lambert, \& Beach, 2010), parenting (e.g., Brelsford, 2013; Weyand, O'Laughlin, \& Bennett, 2013), and even the body (e.g., Homan \& Boyatzis, 2009; Jacobson, Hall, \& Anderson, 2013). More specifically, sexual sanctification (Hernandez et al., 2011; Hernandez-Kane \& Mahoney, 2018; MurraySwank et al., 2005) explores how religious individuals may believe in a spiritual dimension of sexuality, and how that perspective may heighten affect during and after the sexual experience. It involves a "setting apart" of sexuality from the ordinary, denoting a consecration to God. Regardless of debates concerning perception or reality about the sacred, reporting sanctification is real in its consequences; evidence suggests that reporting something to be sacred influences the way someone treats the aspect of life that has been "set apart" (for a more extensive review of studying the sacred, see Pargament, Oman, Pomerleau, \& Mahoney, 2017).

On a more specific empirical note, sexual sanctification has been linked to higher sexual satisfaction, sexual intimacy, marital satisfaction, and spiritual intimacy (Hernandez et al., 2011). Additionally, greater sanctification of marital sexuality early in marriage has predicted more frequent sexual intercourse, sexual satisfaction, and marital satisfaction one year later (Hernandez-Kane \& Mahoney, 2018). Therefore, research suggests that religiosity could positively influence sexual satisfaction by imbuing the sexual relationship with a sanctified, divine sense of meaning.

\section{Gender Considerations}

An additional, understudied consideration is whether there might be any differences in how religiosity influences sexual meaning making and sexual satisfaction for women in comparison to men. Some have asserted that Christian theology (a theology belonging to a high percentage of our participants) emphasizes the "dangers" of female sexuality, without giving the same attention to male sexuality (Farley, 1976; Nicolson, 1993). Additionally, ample research has shown differences between men and women in the 
domain of sexuality (e.g., Leonhardt \& Willoughby, 2017; McClelland, 2010; Petersen \& Hyde, 2010) and religiosity (e.g., Ahrold \& Meston, 2010; Luquis, Brelsford, \& Rojas-Guyler, 2012). On average, men tend to be more permissive than women in their sexual attitudes (Petersen \& Hyde, 2010) and women tend to be more religious than men (e.g., Ahrold \& Meston, 2010; Luquis et al., 2012). More specific to our study, women are significantly more likely than men to experience sexual guilt and anxiety (Emmers-Sommer et al., 2018; Oliver \& Hyde, 1993; Petersen \& Hyde, 2010). These differences in sexual attitudes (particularly sexual guilt; Emmers-Sommer et al., 2018; Oliver \& Hyde, 1993), and religiosity (Ahrold \& Meston, 2010; Luquis et al., 2012), justify conducting separate analyses for men and women.

\section{Current Study}

In line with a dualistic perspective, religiosity seems to have the potential to lead to either sexual guilt or sexual sanctification. By evaluating religiosity's indirect pathways to sexual satisfaction through both sexual guilt and sexual sanctification, with a national sample of 1,614 adults in long-term, committed relationships, we hoped to provide a first empirical look at religiosity's potential for duality in the sexual relationship. To help ensure our sample consisted of committed individuals, we required participants to be in a sexual relationship at least two years, as this is approximately the period when partners become more securely attached to each other and some of the early, obsessive romantic love often starts to wane (Mikulincer \& Shaver, 2016). Although commitment in a relationship likely plays an important role for some couples in whether someone feels sexual guilt or sexual sanctification, it is important to note that most religious teachings are particularly restrictive of sexual behavior outside of a heterosexual marriage (DeLamater, 1981; Miracle et al., 2003). This could make marital status an important control throughout our analyses. On the basis of previous research highlighted in our review, we proposed the following hypotheses and research questions (RQs):

H1: Sexual guilt will be negatively associated with sexual satisfaction, whereas sexual sanctification will be positively associated with sexual satisfaction.

$H 2$ : Religiosity will be positively associated with both sexual guilt and sexual sanctification.

$H 3$ : Religiosity will have an indirect effect on sexual satisfaction through sexual guilt and sexual sanctification.

RQ1: What are the similarities or differences for men and women?

$R Q 2$ : What role does marital status play in these associations?

\section{Method}

\section{Sample and Procedure}

The sample of the present study consisted of 1,614 sexually active individuals (606 men; 1,008 women) sampled from the Amazon Mechanical Turk (MTurk) website (http://www.mturk .com), who had been in a committed, romantic relationship for at least two years and were residents of the United States. MTurk is a website dedicated to online labor and is used to employ "workers" from around the world to complete specific tasks. The study was approved by the institutional review board. Regarding the current project, a job was posted inviting participants to complete a short survey on sexuality in a relationship. Participants were instructed that they needed to be English speaking, and those who were interested were directed to a separate website (Qualtrics) to complete an online assessment. Before beginning the online survey, participants were asked to indicate informed consent and were informed about their rights as a research participant. Upon completion of the survey, participants were thanked for their time and given compensation of $\$ 0.50$. Scholars have noted that samples from MTurk are very similar to other diverse behavioral research samples, and several scholars have replicated previous research results on MTurk to provide evidence for the validity of the sample (Paolacci, Chandler, \& Ipeirotis, 2010; Suri \& Watts, 2011). Full demographic descriptive statistics are listed in Table 1.

\section{Measures}

Religiosity. Four items were used to assess global religiosity: "Spirituality is an important part of my life" $(1=$ never, $5=$ very often), "How often do you pray (commune with a higher power)?" $(1=$ never, 5 = very often $)$, "How important is your religious faith to you" ( 1 = not important, 5 = very important $)$, and "How often do you attend religious services?" $(1=$ never, $5=$ weekly $)$. The Cronbach's alpha was acceptable for both men (.92) and women (.90). ${ }^{1}$

Sexual guilt. Each individual answered the following question, "I experience guilt or anxiety when it comes to my sex life." Responses ranged on a five-point Likert scale $(1=$ strongly disagree, 5 = strongly agree). The item came from the Sexual History and Adjustment Questionnaire (Lewis \& Janda, 1988).

Sexual sanctification. An adaptation of Hernandez et al. (2011) sanctification of sexuality measure, specifically the 10-item Sacred Qualities subscale, was utilized to assess sexual sanctification in the relationship (e.g., "Our sexual relationship is holy," "The sexual bond I have with my partner is sacred to me"). The only adaptation was using language inclusive of committed relationships broadly rather than referring explicitly to marriage (a similar approach to Fincham et al., 2010). Responses ranged on a seven-point Likert scale $(1=$ strongly disagree, $7=$ strongly agree). The Cronbach's alpha was .95 for both men and women.

Sexual satisfaction. The Global Measure of Sexual Satisfaction (GMSEX; Lawrance \& Byers, 1995) was created to assess overall sexual satisfaction. The GMSEX has consistently been

\footnotetext{
${ }^{1}$ Because our measure of global religiosity consisted of both subjective valuation of religiosity as well as a report of behavior, we conducted several supplementary analyses to be more confident in our findings. Our SEM using religiosity without the behavior item was consistent with our reported results. There were also no major changes to results if the subjective valuation scale and behavior item were evaluated as separate variables in the final SEM. The overall story was consistent of religiosity connected to sexual satisfaction primarily through sexual sanctification Because of (a) the high factor loadings of each item onto global religiosity and because (b) the difference of intrinsic versus extrinsic religiosity was not a key component of our research question, we decided the most appropriate course of action was model the four items as indicators of global religiosity in the analyses. Full results are available on request.
} 
Table 1

Descriptive Statistics for Demographic Variables

\begin{tabular}{|c|c|c|c|}
\hline Variable & $M$ or $\%$ & $S D$ & Range \\
\hline Age & 34.47 & 9.36 & $18-80$ \\
\hline Relationship length & 98.81 & 89.29 & $24-660$ \\
\hline \multicolumn{4}{|l|}{ Gender } \\
\hline Men & $37.4 \%$ & & \\
\hline Women & $62.6 \%$ & & \\
\hline \multicolumn{4}{|l|}{ Sexual orientation } \\
\hline Heterosexual & $85.0 \%$ & & \\
\hline Sexual minority & $15.0 \%$ & & \\
\hline \multicolumn{4}{|l|}{ Race } \\
\hline White & $77.9 \%$ & & \\
\hline Asian & $4.7 \%$ & & \\
\hline African & $6.5 \%$ & & \\
\hline Latino & $6.2 \%$ & & \\
\hline Mixed/biracial & $3.6 \%$ & & \\
\hline Native American & $.6 \%$ & & \\
\hline Other & $.6 \%$ & & \\
\hline \multicolumn{4}{|l|}{ Relationship status } \\
\hline Married & $55.6 \%$ & & \\
\hline Cohabiting & $27.1 \%$ & & \\
\hline Dating, never married & $13.4 \%$ & & \\
\hline Other & $3.9 \%$ & & \\
\hline \multicolumn{4}{|l|}{ Education } \\
\hline High school or less & $10.0 \%$ & & \\
\hline Some college & $41.7 \%$ & & \\
\hline 4-year degree & $33.4 \%$ & & \\
\hline Advanced & $14.8 \%$ & & \\
\hline \multicolumn{4}{|l|}{ Income } \\
\hline None & $6.5 \%$ & & \\
\hline Under $\$ 20,000$ & $18.2 \%$ & & \\
\hline$\$ 20,000-39,999$ & $25.7 \%$ & & \\
\hline$\$ 40,000-59,999$ & $22.6 \%$ & & \\
\hline$\$ 60,000-79,999$ & $13.2 \%$ & & \\
\hline$\$ 80,000+$ & $13.6 \%$ & & \\
\hline \multicolumn{4}{|l|}{ Religious affiliation } \\
\hline Christian & $48.7 \%$ & & \\
\hline Atheist & $9.1 \%$ & & \\
\hline Agnostic & $13.2 \%$ & & \\
\hline No affiliation & $19.5 \%$ & & \\
\hline Other & $9.5 \%$ & & \\
\hline \multicolumn{4}{|l|}{ Number of children } \\
\hline 0 & $44.6 \%$ & & \\
\hline 1 & $19.8 \%$ & & \\
\hline 2 & $21.0 \%$ & & \\
\hline $3+$ & $14.6 \%$ & & \\
\hline
\end{tabular}

shown to have some of the strongest psychometric validity among sexual satisfaction measures (Mark, Herbenick, Fortenberry, Sanders, \& Reece, 2014). The GMSEX has a root question of "In general, how would you describe your sexual relationship with your partner?" The participants then respond to five separate items, each on a seven-point scale, in reporting their overall sexual satisfaction: (1) good-bad, (2) pleasant-unpleasant, (3) positivenegative, (4) satisfying-unsatisfying, and (5) valuable-worthless. Our sample had high reliability for men $(\alpha=.95)$ and women $(\alpha=.96)$.

Control variables. Age, relationship length, and number of children were each assessed with open ended questions. Race, sexual orientation, and marital status were dichotomized so that all participants were coded as either White (1) or non-White (0), heterosexual (1) or nonheterosexual (0), and married (1) or nonmarried (0). Education was assessed on a seven-point scale $(1=$ less than high school, $7=$ doctorate; e.g., $\mathrm{PhD}, \mathrm{JD}, \mathrm{MD})$, and income was assessed on a 12-point scale $(1=$ none, $12=$ $\$ 300,000$ or above). Marital status was a particularly important control, as some scholars have suggested that sexual guilt from religion may be unique to unmarried individuals (Hackathorn et al., 2016). ${ }^{2}$

\section{Data Analysis Plan}

We first conducted preliminary analyses to gain greater insight into our variables of interest and explore whether we were justified in splitting our analyses by gender. We conducted a multivariate analysis of variance (MANOVA) by gender (see Table 2), bivariate correlations (see Table 3), and measurement invariance tests. After determining it was appropriate to split the sample by gender (see further details in results section), we estimated a series of structural equation models (SEM) each increasing in complexity. For the MANOVA by gender and bivariate correlations, the items for constructs were averaged together to create a mean score for scales of interest. For both the measurement models and subsequent SEM models, all individual items of scales were modeled onto latent variables for their corresponding constructs.

We first estimated measurement models to increase confidence in the validity of these latent variables. This is an appropriate preliminary step detailed by Kline (2016) to help ensure that each item adequately loads onto the appropriate corresponding latent construct while all latent variables are taken into account simultaneously. This increases confidence that each latent construct is a good fit for the data before modeling additional observed variables and regression pathways that complicate the model. We then created SEM models for men and women to estimate the direct effect of religiosity on sexual satisfaction with all controls inserted. Age, race, education, income, relationship length, sexual orientation, number of children, and marital status were used as controls in these models. Finally, we inserted sexual sanctification, and sexual guilt as variables between religiosity and sexual satisfaction and conducted 5,000 bootstraps to obtain results for indirect effects (see Figure 1 for the hypothesized model). All analyses were conducted in MPlus 7.11 (Muthén \& Muthén, 1998-2012).

\section{Results}

\section{Preliminary Analyses}

Gender MANOVA. Gender differences were explored for all the variables. A MANOVA revealed an overall significant gender difference: Wilks $\lambda=.866, F(26,3204)=9.16, p<.001$, partial eta-square $=.07$. Levene's test suggested that homogeneity of variance was violated for income $(p<.001)$, sexual orientation $(p<$ .001 ), and sexual guilt $(p<.001)$. Accordingly, group comparisons between men and women for variables where Levene's test was significant should be interpreted with caution. Table 2 shows means, standard deviations, and $F$ values for each variable.

\footnotetext{
${ }^{2}$ In addition to our primary analyses where we controlled for marital status, we conducted supplementary analyses to assess whether all findings were consistent across unmarried and married individuals. For this particular sample there were no differences in findings for our constructs of interest for those that were married as opposed to those who were unmarried (results available on request).
} 
Table 2

Descriptive Statistics and Gender Differences of Control, Independent, and Dependent Variables

\begin{tabular}{|c|c|c|c|c|c|c|}
\hline \multirow[b]{2}{*}{ Variable } & \multicolumn{2}{|c|}{ Men } & \multicolumn{2}{|c|}{ Women } & \multirow[b]{2}{*}{ Response range } & \multirow[b]{2}{*}{$F$} \\
\hline & $M$ & $S D$ & $M$ & $S D$ & & \\
\hline Age & 36.17 & 10.91 & 33.47 & 10.34 & $18-80$ & $24.69^{\text {**** }}$ \\
\hline White & .79 & .41 & .78 & .42 & $0-1$ & .21 \\
\hline Education & 4.40 & 1.38 & 4.06 & 1.25 & $1-7$ & $25.74^{* * * *}$ \\
\hline Income & 4.33 & 2.02 & 3.42 & 1.60 & $1-12$ & $100.47^{* * * *}$ \\
\hline Relationship length (months) & 102.31 & 89.45 & 96.86 & 89.48 & $24-660$ & 1.4 \\
\hline Number of children & 1.06 & 1.29 & 1.23 & 1.89 & $1-7$ & $3.94^{*}$ \\
\hline Heterosexual & .90 & .31 & .83 & .38 & $0-1$ & $14.22^{* * * *}$ \\
\hline Married & .57 & .50 & .55 & .50 & $0-1$ & .51 \\
\hline Religiosity & 2.72 & 1.30 & 2.84 & 1.25 & $1-5$ & 3.45 \\
\hline Sexual guilt & 1.95 & 1.19 & 2.19 & 1.34 & $1-5$ & $12.63^{\text {***** }}$ \\
\hline Sexual sanctification & 4.01 & 1.67 & 4.01 & 1.67 & $1-7$ & .01 \\
\hline Sexual satisfaction & 5.68 & 1.40 & 5.76 & 1.40 & $1-7$ & 1.23 \\
\hline
\end{tabular}

${ }^{*} p<.05 . \quad{ }^{* * *} p<.001$.

Bivariate associations. We then assessed the bivariate associations between the variables of interest for each gender. For parsimony, we do not report here all the significant correlations (see Table 3 for full results), but we note some of the most important findings. As expected, religiosity was associated with higher sexual sanctification (men: $r=.50, p<.001$; women: $r=$ $.34, p<.001)$. However, religiosity was not related to sexual guilt (men: $r=.03, p=.45$; women: $r=.04, p=.18$ ), or sexual satisfaction (men: $r=.07, p=.08$; women: $r=-.01, p=.79$ ). However, sexual sanctification was positively associated with sexual satisfaction (men: $r=.37, p<.001$; women: $r=.45, p<$ $.001)$ and sexual guilt was negatively associated with sexual satisfaction (men: $r=-.39, p<.001$; women: $r=-.35, p<.001$ ). Also of interest, sexual guilt and sexual sanctification only had a small (men: $r=-.11, p<.01$ ) to moderate (women: $r=-.20$, $p<.001)$ negative correlation.

Measurement invariance. We found that the sexual sanctification measure failed to meet the assumption for strong invariance: $\chi^{2}$ difference $(10)=44.896, p<.001$, suggesting that the construct does not meet the necessary conditions for direct comparison between men and women (Dyer, 2015; Little, 2013). Considering the (a) violation of Levene's test for sexual guilt, (b) lack of measurement invariance for sexual sanctification, and (c) previous empirical and conceptual work suggesting differences between men and women in the domain of sexuality (Emmers-Sommer et al., 2018; Leonhardt \& Willoughby, 2017; McClelland, 2010; Petersen \& Hyde, 2010), we decided that it would be more appropriate to estimate separate models for each gender rather than making direct comparisons through a multigroup model.

\section{Structural Equation Models}

Measurement models. Both final measurement models fit the data adequately (men: $\chi^{2}[143]=580.44, \mathrm{CFI}=.96, p<.001$, RMSEA $=.07$, SRMR $=.06$; women: $\chi^{2}[138]=841.30, p<$ $.001, \mathrm{CFI}=.97$, RMSEA $=.07$, SRMR $=.06$ ). All factor loadings were above .47 for both men and women.

Nonindirect effects structural equation models. The models had good fit $\left(\right.$ men: $\chi^{2}[82]=194.25, p<.01 \mathrm{CFI}=.98$, RMSEA $=.05$, SRMR $=.03$; women: $\chi^{2}[82]=254.87, p<.001$, $\mathrm{CFI}=.98, \mathrm{RMSEA}=.05, \mathrm{SRMR}=.02)$. For men, religiosity was positively associated with sexual satisfaction $(\beta=.13, p<$

Table 3

Bivariate Correlations Between Control Variables, Independent Variables, and Outcome Variables

\begin{tabular}{|c|c|c|c|c|c|c|c|c|c|c|c|c|}
\hline Variable & 1 & 2 & 3 & 4 & 5 & 6 & 7 & 8 & 9 & 10 & 11 & 12 \\
\hline 1. Age & - & $.11^{* * * * *}$ & .06 & $.20^{* * * * *}$ & $.58^{* * * * *}$ & $.27^{* * * *}$ & $.14^{* * * *}$ & $.22^{* * * *}$ & $.22^{* * * *}$ & $-.09^{* *}$ & -.02 & $-.14^{* * * * *}$ \\
\hline 2. White & $.15^{\text {**** }}$ & - & .04 & .04 & $.11^{* * * *}$ & .03 & - & - & $-.09^{* *}$ & .00 & -.05 & .03 \\
\hline 3. Education & $.18^{* * * *}$ & .05 & - & $.24^{* * * *}$ & .01 & $-.09^{*}$ & .03 & $.07^{*}$ & .00 & .02 & $-.11^{* * * *}$ & -.04 \\
\hline 4. Income & $.23^{* * * *}$ & .05 & $.38^{* * * * *}$ & - & $.13^{* * * * *}$ & .02 & .06 & $.15^{* * * * *}$ & $.07^{*}$ & .04 & .05 & .01 \\
\hline 5. Relationship length & $.59^{* * * *}$ & $.13^{* *}$ & $.15^{* * * *}$ & $.22^{* * * *}$ & - & $.22^{\text {***** }}$ & $.11^{* * * *}$ & $.43^{\text {**** }}$ & $.17^{* * * *}$ & -.02 & -.01 & $-.08^{\text {*** }}$ \\
\hline 6. Number & $.40^{* * * *}$ & .07 & .05 & $.21^{* * * *}$ & $.43^{* * *}$ & - & $.11^{* * * *}$ & $.17^{\text {**** }}$ & $.21^{* *}$ & .03 & .05 & -.06 \\
\hline 7. Heterosexual & $.09^{*}$ & - & .04 & $.11^{* *}$ & $.14^{* * * *}$ & $.09^{*}$ & - & & $.25^{* * * *}$ & -.05 & $.06^{*}$ & -.03 \\
\hline 8. Married & $.37^{* * * * *}$ & - & $.23^{* * * * *}$ & $.33^{* * * *}$ & $.50^{* * * * *}$ & $.41^{* * * * *}$ & - & - & $.15^{\text {***** }}$ & .06 & .00 & -.05 \\
\hline 9. Religiosity & $.22^{* * * *}$ & $-.13^{* *}$ & $.13^{* * *}$ & $.15^{* * * *}$ & $.19^{* * * *}$ & $.28^{* * * *}$ & $.12^{* *}$ & $.21^{* * * *}$ & - & .04 & $.34^{* * * * *}$ & -.01 \\
\hline 10. Sexual guilt & .05 & .01 & .04 & -.06 & .02 & .04 & $-.09^{*}$ & .01 & .03 & - & $-.20^{* * * * *}$ & $-.35^{* * * *}$ \\
\hline 11. Sexual sancti & .06 & $-.12^{* * *}$ & .01 & .05 & .05 & $.14^{* * * *}$ & $.12^{* * *}$ & $.09^{*}$ & $.49^{* * *}$ & $-.11^{* * *}$ & -20 & $.45^{* * * *}$ \\
\hline 12. Sexual satisfaction & $-.16^{* * * *}$ & $-.10^{*}$ & -.05 & -.02 & $-.14^{* * * *}$ & $-.11^{* * *}$ & .04 & $-.14^{* * *}$ & .07 & $-.39^{* * * * *}$ & $.37^{* * * * *}$ & - \\
\hline
\end{tabular}

Note. Men's correlations are below the diagonal. Women's correlations are above the diagonal. Correlations between two dichotomous variables are precluded.

${ }^{*} p<.05 . \quad{ }^{* * *} p<.01 .^{* * * *} p<.001$. 


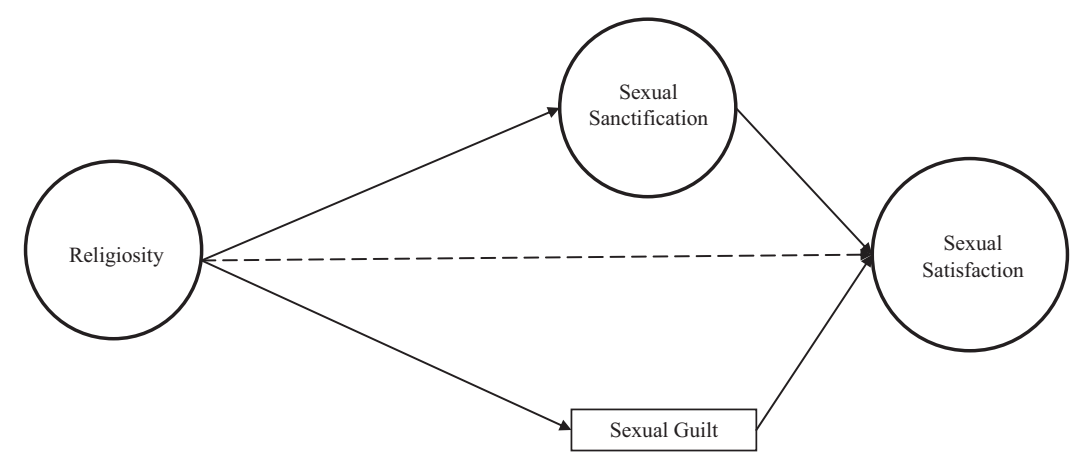

Figure 1. Hypothesized model of indirect effects. Model will control for age, race, education, income, sexual orientation, number of children, relationship length, and marital status.

$.01)$. Of the control variables, age was negatively associated with sexual satisfaction $(\beta=-12, p=.02)$. For women, religiosity was not associated with sexual satisfaction $(\beta=.05, p=.20)$. Of the control variables, age $(\beta=-14, p<.01)$, was negatively associated with sexual satisfaction. The models predicted a small amount of the variance of sexual satisfaction for both men $\left(R^{2}=\right.$ $.06)$ and women $\left(R^{2}=.03\right)$.

Indirect effects model for men. The model had adequate fit $\left(\chi^{2}[287]=814.45, p<.001 \mathrm{CFI}=.96, \mathrm{RMSEA}=.06, \mathrm{SRMR}=\right.$ $.05)$, and predicted small variance for sexual guilt $\left(R^{2}=.02\right)$, and moderate variance for sexual sanctification $\left(R^{2}=.31\right)$ and sexual satisfaction $\left(R^{2}=.29\right)$. Sexual sanctification was positively associated with sexual satisfaction $(\beta=.35, p<.001)$, and sexual guilt was negatively associated with sexual satisfaction $(\beta=-.35, p<.001)$. Model 1a in Table 4 lists all other direct effects.

Religiosity had a significant total effect on sexual satisfaction $(\beta=$ $.13, p=.03,95 \%$ CI $[.06, .21])$, and a significant indirect effect on sexual satisfaction $(\beta=.18, p<.001,95 \%$ CI $[.12, .24])$. Specifically, it had a positive indirect effect through sexual sanctification $(\beta=.19, p<.001,95 \%$ CI $[.14, .25])$. See Table 5 for full results of indirect effects.
Indirect effects model for women. The model had adequate fit, $\chi^{2}(287)=1390.05, p<.001 \mathrm{CFI}=.95$, RMSEA $=.06$, $\mathrm{SRMR}=.05$, and predicted small variance for sexual guilt $\left(R^{2}=.02\right)$ and sexual sanctification $\left(R^{2}=.17\right)$, and moderate variance for sexual satisfaction $\left(R^{2}=.29\right)$. Sexual sanctification was positively associated with sexual satisfaction $(\beta=.40, p<.001)$, and sexual guilt was negatively associated with sexual satisfaction $(\beta=-.29, p<.001)$. Model $1 \mathrm{~b}$ in Table 4 lists all other direct effects.

Interestingly, religiosity did not have a significant total effect on sexual satisfaction $(\beta=.05, p=.19,95 \% \mathrm{CI}[-.01, .10])$, but it did have a positive indirect effect on sexual satisfaction $(\beta=.17, p<$ $.001,95 \%$ CI $[.10, .18])$. Specifically, it had a positive indirect effect through sexual sanctification ( $\beta=.16, p<.001,95 \%$ CI $[.13, .19])$, and a negative direct effect $(\beta=-.10, p<.01,95 \% \mathrm{CI}[-.15,-.04])$ independent of any mediator. See Table 5 for full results of indirect effects.

\section{Discussion}

Consistent with previous research, our first hypothesis (H1) was supported, as sexual guilt was negatively associated with sexual

Table 4

Model of Direct Effects Predicting Sexual sanctification, Sexual guilt, and Sexual Satisfaction

\begin{tabular}{|c|c|c|c|c|c|c|}
\hline \multirow[b]{3}{*}{ Variable } & \multicolumn{3}{|c|}{ Model 1a } & \multicolumn{3}{|c|}{ Model 1b } \\
\hline & \multicolumn{3}{|c|}{$\operatorname{Men}(\beta)$} & \multicolumn{3}{|c|}{ Women $(\beta)$} \\
\hline & $\begin{array}{c}\text { Sexual } \\
\text { Sanctification }\end{array}$ & $\begin{array}{c}\text { Sexual } \\
\text { Guilt }\end{array}$ & $\begin{array}{c}\text { Sexual } \\
\text { Satisfaction }\end{array}$ & $\begin{array}{c}\text { Sexual } \\
\text { Sanctification }\end{array}$ & $\begin{array}{c}\text { Sexual } \\
\text { Guilt }\end{array}$ & $\begin{array}{c}\text { Sexual } \\
\text { Satisfaction }\end{array}$ \\
\hline Age & -.05 & .06 & -.08 & $-.10^{*}$ & $-.12^{* *}$ & $-.14^{* * * *}$ \\
\hline White & -.05 & .00 & -.03 & -.01 & .01 & $.06^{*}$ \\
\hline Education & -.03 & .07 & -.00 & $-.12^{* * * *}$ & .03 & .01 \\
\hline Income & .00 & $-.10^{*}$ & -.02 & $.09^{* * *}$ & -.05 & -.00 \\
\hline Relationship length & -.05 & -.01 & -.02 & -.02 & .02 & -.01 \\
\hline Number of children & .04 & .03 & -.08 & .02 & -.02 & -.04 \\
\hline Heterosexual & .06 & -.09 & -.00 & -.01 & -.05 & -.03 \\
\hline Married & .02 & .01 & $-.09^{*}$ & -.02 & .08 & .02 \\
\hline Religiosity & $.54^{* * * *}$ & .03 & -.05 & $.40^{\text {***** }}$ & .07 & $-.10^{* * *}$ \\
\hline Sexual sanctification & & & $.35^{* * * *}$ & & & $.40^{* * * *}$ \\
\hline Sexual guilt & & & $-.35^{* * * *}$ & & & $-.29^{* * * *}$ \\
\hline$R^{2}$ & .31 & .02 & .29 & .17 & .02 & .29 \\
\hline
\end{tabular}

Note. $\quad$ Model 1a: $\chi^{2}(287)=814.45, p<.001, \mathrm{CFI}=.96, \mathrm{RMSEA}=.06, \mathrm{SRMR}=.05 ;$ Model 1b: $\chi^{2}(287)=$ $1390.05, p<.001, \mathrm{CFI}=.95, \mathrm{RMSEA}=.06, \mathrm{SRMR}=.05$

${ }^{*} p<.05 .{ }^{* *} p<.01$. $^{* * *} p<.001$. 
Table 5

Model of Total, Indirect, and Direct Effects Predicting Sexual Sanctification, Sexual Guilt, and Sexual Satisfaction

\begin{tabular}{|c|c|c|c|c|c|c|}
\hline \multirow[b]{3}{*}{ Direct, Indirect, and Total Effects } & \multicolumn{3}{|c|}{ Model 1a } & \multicolumn{3}{|c|}{ Model 1b } \\
\hline & \multicolumn{3}{|c|}{ Men } & \multicolumn{3}{|c|}{ Women } \\
\hline & $\beta$ & $S E$ & CI & $\beta$ & $S E$ & CI \\
\hline Religiosity $\rightarrow$ Sexual Satisfaction (direct effect) & -.05 & .05 & {$[-.14, .04]$} & $-.10^{* * *}$ & .04 & {$[-.15,-.04]$} \\
\hline Religiosity $\rightarrow$ Sexual Sanctification $\rightarrow$ Sexual Satisfaction & $.19^{* * * *}$ & .03 & {$[.14, .25]$} & $.16^{* * * *}$ & .02 & {$[.13, .19]$} \\
\hline Religiosity $\rightarrow$ Sexual Guilt $\rightarrow$ Sexual Satisfaction & -.01 & .02 & {$[-.04,02]$} & -.02 & .01 & {$[-.04, .00]$} \\
\hline Religiosity $\rightarrow$ Sexual Satisfaction (total indirect) & $.18^{* * * *}$ & .04 & {$[.12,24]$} & $.14^{* * * *}$ & .02 & {$[.10, .18]$} \\
\hline Religiosity $\rightarrow$ Sexual Satisfaction (total effect) & $.13^{* * *}$ & .05 & {$[.06, .21]$} & .05 & .04 & {$[-.01, .10]$} \\
\hline
\end{tabular}

*** $p<.01 .{ }^{* * *} p<.001$.

satisfaction (Hackathorn et al., 2016; Higgins et al., 2010), and sexual sanctification was positively associated with sexual satisfaction (Hernandez et al., 2011; Hernandez-Kane \& Mahoney, 2018). This follows the logic of previous research, as the uncomfortable, inhibiting feelings of sexual guilt are likely to be connected to greater difficulty enjoying a sexual experience. Alternatively, the peace, transcendence, and divine meaning making of sexual sanctification should be connected to more satisfying sexual experience. Perhaps the most unique insight our study offers into these findings is the clear distinction between and unique associations of sexual guilt and sexual sanctification. The two constructs only had a small negative correlation between each other, and independently had a moderate association with sexual satisfaction in the full structural model. Perhaps future work in sexuality would benefit from the simultaneous evaluation of positive and negative sexual attitudes and meaning making with more in-depth measures.

Our second hypothesis (H2), that religiosity would be positively associated with both sexual guilt and sexual sanctification, was partially supported. Although religiosity was consistently associated with sexual sanctification for both men and women in both the bivariate correlations and the structural equation model, the same did not hold true for sexual guilt. Religiosity was not related to sexual guilt for either gender in the bivariate correlations or structural equation models. Holistically, these findings are encouraging for religious individuals, as they suggest the possibility of religiosity instilling a positive message about sexuality (e.g., Hernandez et al., 2014; Lauer, 1985).

Despite no association between religiosity and sexual guilt in this particular study, this does not suggest that researchers should stop searching for better understanding of the connection between religiosity and sexual guilt. It is worth noting that the link between religiosity and sexual guilt seems more likely to exist in unmarried college samples (Hackathorn et al., 2016). Considering we controlled for relationship status and length, and they both had such little predictive power in our final structural equation model, perhaps the association between religiosity and sexual guilt is only found when sexuality is occurring in a casual or uncommitted relationship. In general, future research should consider potential moderators between religiosity and sexual meaning making constructs, as there could be several factors that increase or decrease the likelihood of religiosity shaping someone's views of sexual guilt or sexual sanctification.

Our third hypothesis (H3), that religiosity would have an indirect effect on sexual satisfaction through sexual guilt and sexual sanctification was partially supported, with some interesting gendered nuances. The results for men were in line with our hypothesis. In the model without sexual sanctification or sexual guilt, men's religiosity had a small, positive association with sexual satisfaction. However, when both sexual guilt and sexual sanctification were added to the model, the direct effect disappeared. Interestingly, there was no indirect effect through sexual guilt, suggesting that the association between religiosity and sexual satisfaction only exists insofar as religiosity leads to sexual sanctification. We interpret this result with caution, as multiple waves of longitudinal data are needed to truly understand indirect effects. However, for men, it appears that religiosity is only positively related to sexual satisfaction insofar that men utilize their religious experience to develop a sanctified view of sexuality. These results support previous suggestions by scholars about the importance of considering potential explanatory variables between religiosity and sexual satisfaction to help clarify the associations (Hackathorn et al., 2016; Hardy \& Willoughby, 2017).

The results for women were more nuanced and perhaps provide some of the clearest evidence for dualities pointed out in previous research (Dollahite et al., 2018; Mahoney, 2010; Mahoney et al., 2001). Interestingly, no association was found between religiosity and sexual satisfaction in the model without sexual guilt or sexual sanctification, but the indirect effects explored after adding sexual guilt and sexual sanctification provide a complicated picture. Religiosity had a small, positive, indirect effect on sexual satisfaction through sexual sanctification. Yet, with all these variables accounted for simultaneously, religiosity also had a small negative direct effect on sexual satisfaction, resulting in no association for the total effect. This finding is somewhat similar to a previous study showing that greater initial frequency of prayer significantly predicted less sexual satisfaction longitudinally when simultaneously accounting for sanctification (Hernandez-Kane et al., 2018). Overall, the association between religiosity and sexual satisfaction for women is dualistic and complex. Although the negative association between religiosity and sexual satisfaction was not accounted for with the sexual guilt item, religiosity seemed to be connected to a conflicting influence on women's sexual satisfaction when controlling for sexual sanctification. The negative direct effect from religiosity to sexual satisfaction after accounting for sexual sanctification suggests there may be religious factors we were unable to account for that negatively influence women's sexual satisfaction (Farley, 1976; Nicolson, 1993; Woo et al., 2012). 
Future research should consider potential explanatory variables for this negative association for women. Perhaps inhibition surrounding sexuality could be a unique mediator between religiosity and sexual satisfaction, stemming from a message de-emphasizing sexual expression (Freud, 1927/1961), sometimes more specifically gendered toward women (Farley, 1976; Nicolson, 1993). Or perhaps religious women receive less comprehensive sexual education, resulting in less knowledge of sexual anatomy and functioning, leading to a less fulfilling sexual relationship. The complicated nature of female sexual anatomy likely makes knowledge of sexual functioning more crucial for women than men in having a fulfilling sexual experience. Amid these speculations, it is important to keep in mind that this negative direct effect was only found after accounting for sexual sanctification.

\section{Limitations and Future Directions}

Although our study had several strengths, such as advancing a theory on religious dualities (Dollahite et al., 2018; Mahoney, 2010; Mahoney et al., 2001) a large national sample, and advanced methodology for complex hypotheses, the study did have a number of limitations. One limitation was the use of Mechanical Turk as a sampling frame. Although we went through a lengthy process to ensure the responses to the questionnaire were high in quality, researchers should attempt to replicate these findings in a more representative sample.

A second limitation is the cross-sectional nature of the study, as it precludes causal or directional evidence. We are confident in the theoretical reasoning suggesting that religiosity can influence attitudes and meaning surrounding sexuality (e.g., Emmers-Sommer et al., 2018; Woo et al., 2012), which in turn can influence sexual satisfaction (e.g., Hackathorn et al., 2016; Hardy \& Willoughby, 2017; Hernandez et al., 2011). However, the possibility remains for inverse associations. Perhaps feelings of sexual guilt could result in someone turning to religiosity as an act of recompense. Perhaps a sanctified experience with sexuality might lead someone to search out religiosity to make better sense of their transcendence. Some time periods that might be interesting to evaluate longitudinally include the transition from unmarried to married, or from childlessness to parenthood, as these adjustments may bring dramatic life changes that alter one's views of the relationship, as well as sexuality within the relationship.

Limitations also existed with measurement. Sexual sanctification was assessed with only a nontheistic Sacred Qualities of Sexuality subscale, rather than as part of the whole sanctification measure that includes the Manifestation of God subscale (Hernandez et al., 2011). Furthermore, the subscale was revised to be more inclusive of nonmarried individuals, making it difficult to assess the extent these results are directly comparable to other studies (e.g., Hernandez et al., 2011; Hernandez-Kane \& Mahoney, 2018) on sexual sanctification, specifically in marital relationships. However, this approach has been utilized before by broadening a marital sanctification measure to a relationship sanctification measure (Fincham et al., 2010). Perhaps additional studies can further explore how some of these subscales might play out differently in marriage versus other committed relationships. It is interesting to note that many committed couples, who are not married, view their sexual unions through a sacred lens, despite organized religions teaching that sacred sex should be reserved for marriage (Hernan- dez et al., 2014). Perhaps a better understanding of how sanctification plays out differently across married individuals and highly committed unmarried individuals could be nuanced by the meaning individuals attach to marriage itself (Willoughby \& James, 2017).

Sexual guilt was assessed with one item, leaving us unable to fully account for the reliability and validity of the construct (DeVellis, 1991). An additional concern with the item is that it asked about whether someone experienced sexual guilt or anxiety. This ambiguity in measurement is certainly a limitation, as guilt and anxiety are not necessarily the same thing. Future researchers should use a full scale for the construct to ensure the validity of these results. It would be beneficial for scholars to further investigate this matter with a more sophisticated measurement of sexual guilt (perhaps the Moser Sex-Guilt Scale; Janda \& Bazemore, 2011) separate from sexual anxiety to tease out these nuances with greater depth and clarity. Overall, these measurement limitations, particularly the one item for sexual guilt, preclude clear conclusions, and mark a beginning point for investigating the dualities of religiosity.

Other interesting future directions might be to assess how this positive and negative meaning making surrounding sexuality might exist simultaneously. For example, someone may experience a unique conflict if she or he received mixed messages about the positive and negative nature of sexuality from religious leaders (e.g., sexuality is a necessary evil for the good of procreation). More fully exploring the influence of both positive and negative effects may help to fully understand the recent theoretical assertions on religious dualities (Dollahite et al., 2018; Hernandez et al., 2014; Mahoney, 2010). It would also be beneficial to assess other dimensions of sexuality, such as sexual frequency and sexual intimacy. Although this study included sexual orientation as a control, it could be interesting to delve more deeply into sexual orientation differences on this topic, as some religions prohibit nonheterosexual sexual relations (Hernandez et al., 2014). It would also be beneficial to more fully consider the multifaceted nature of religiosity, evaluating beliefs, practices, and communities, as well as assessing whether any differences are found amid different religious affiliations (e.g., Dollahite et al., 2004; Hardy \& Willoughby, 2017).

\section{Conclusion}

We have highlighted the complication and duality between religiosity and sexuality. Although the study provides some encouraging results for religious individuals by showing religiosity's potential to positively influence sexual satisfaction through sexual sanctification (particularly for men), the encouraging finding is blunted with the inconsistent positive and negative connection between religiosity and sexual satisfaction for women. Researchers and clinicians should be wary of religiosity's potential for harm in the sexual domain. Religious teachings can include a negative, sometimes even intensely negative messages about sexuality (e.g., Boulder, 1998; Schnarch, 1991) that can be guilt inducing (e.g., Emmers-Sommer et al., 2018; Hackathorn et al., 2016) and in extreme cases even crippling to a sexual relationship (Ley, 2017). However, all should be equally aware of religion's potential for good in the sexual domain, as a sanctified sexual experience can be a conduit for transcendence, bliss, peace, and even healing for 
committed couples (Hernandez et al., 2011; Kleinplatz et al., 2009).

\section{References}

Abbott, D. M., Harris, J. E., \& Mollen, D. (2016). The impact of religious commitment on women's sexual self-esteem. Sexuality \& Culture, 20, 1063-1082. http://dx.doi.org/10.1007/s12119-016-9374-x

Ahrold, T. K., \& Meston, C. M. (2010). Ethnic differences in sexual attitudes of U.S. college students: Gender, acculturation, and religiosity factors. Archives of Sexual Behavior, 39, 190-202. http://dx.doi.org/10 .1007/s10508-008-9406-1

Ashdown, B. K., Hackathorn, J., \& Clark, E. M. (2011). In and out of the bedroom: Sexual satisfaction in the marital relationship. Journal of Integrated Social Sciences, 2, 40-57.

Bartkowski, J. (2001). Remaking the godly marriage. New Brunswick, NJ: Rutgers University Press

Boulder, M. (Trans). (1998). Confessions: St. Augustine. New York, NY: Vintage Books.

Brelsford, G. M. (2013). Sanctification and spiritual disclosure in parentchild relationships: Implications for family relationship quality. Journal of Family Psychology, 27, 639-649. http://dx.doi.org/10.1037/a00 33424

Buss, D. M. (2002). Sex, marriage, and religion: What adaptive problems do religious phenomena solve? Psychological Inquiry, 13, 201-203.

Christopher, F. S., \& Sprecher, S. (2000). Sexuality in marriage, dating, and other relationships: A decade review. Journal of Marriage and the Family, 62, 999-1017. http://dx.doi.org/10.1111/j.1741-3737.2000 .00999.x

Cowden, C. R., \& Bradshaw, S. D. (2007). Religiosity and sexual concerns. International Journal of Sexual Health, 19, 15-24. http://dx.doi.org/10 .1300/J514v19n01_03

Davidson, J. K., Moore, N. B., \& Ullstrup, K. M. (2004). Religiosity and sexual responsibility: Relationships of choice. American Journal of Health Behavior, 28, 335-346. http://dx.doi.org/10.5993/AJHB.28.4.5

Delamater, J. (1981). The social control of sexuality. Annual Review of Sociology, 7, 263-290. http://dx.doi.org/10.1146/annurev.so.07.080181 .001403

DeVellis, R. F. (1991). Scale development: Theory and applications. Newbury Park, CA: SAGE.

Dollahite, D. C., Marks, L. D., \& Dalton, H. (2018). How religion helps and harms families: A conceptual model of a system of dualities at the nexus of faith and family life. Journal of Family Theory \& Review, 10, 219-241. http://dx.doi.org/10.1111/jftr.12242

Dollahite, D. C., Marks, L. D., \& Goodman, M. (2004). Families and religious beliefs, practices, and communities: Linkages in a diverse and dynamic cultural context. In M. J. Coleman \& L. H. Ganong (Eds.), The handbook of contemporary families: Considering the past contemplating the future (pp. 411-431). Thousand Oaks, CA: SAGE. http://dx.doi.org/ 10.4135/9781412976022.n24

Dyer, W. J. (2015). The vital role of measurement equivalence in family research. Journal of Family Theory \& Review, 7, 415-431. http://dx.doi .org/10.1111/jftr.12115

Ellison, C. G., Henderson, A. K., Glenn, N. D., \& Harkrider, K. E. (2011). Sanctification, stress, and marital quality. Family Relations, 60, 404420. http://dx.doi.org/10.1111/j.1741-3729.2011.00658.x

Emmers-Sommer, T. M., Allen, M., Schoenbauer, K. V., \& Burrell, N. (2018). Implications of sex guilt: A meta-analysis. Marriage \& Family Review, 54, 417-437. http://dx.doi.org/10.1080/01494929.2017 .1359815

Farley, M. A. (1976). Sources of sexual inequality in the history of Christian thought. The Journal of Religion, 56, 162-176. http://dx.doi .org/10.1086/486481

Fincham, F. D., \& Beach, S. R. H. (2014). I say a little prayer for you: Praying for partner increases commitment in romantic relationships.
Journal of Family Psychology, 28, 587-593. http://dx.doi.org/10.1037/ a0034999

Fincham, F. D., Beach, S. R. H., Lambert, N., Stillman, T., \& Braithwaite, S. (2008). Spiritual behaviors and relationship satisfaction: A critical analysis of the role of prayer. Journal of Social and Clinical Psychology, 27, 362-388. http://dx.doi.org/10.1521/jscp.2008.27.4.362

Fincham, F. D., Lambert, N. M., \& Beach, S. R. H. (2010). Faith and unfaithfulness: Can praying for your partner reduce infidelity? Journal of Personality and Social Psychology, 99, 649-659. http://dx.doi.org/ $10.1037 / \mathrm{a} 0019628$

Freud, S. (1961). The future of an illusion. New York, NY: Norton. (Original work published 1927)

Hackathorn, J. M., Ashdown, B. K., \& Rife, S. C. (2016). The sacred bed: Sex guilt mediates religiosity and satisfaction for unmarried people. Sexuality \& Culture: An Interdisciplinary Quarterly, 20, 153-172. http://dx.doi.org/10.1007/s12119-015-9315-0

Hardy, S. A., \& Willoughby, B. J. (2017). Religiosity and chastity among single young adults and married adults. Psychology of Religion and Spirituality, 9, 285-295. http://dx.doi.org/10.1037/rel0000112

Hernandez, K. M., Mahoney, A., \& Pargament, K. I. (2011). Sanctification of sexuality: Implications for newlyweds' marital and sexual quality. Journal of Family Psychology, 25, 775-780. http://dx.doi.org/10.1037/ a0025103

Hernandez, K. M., Mahoney, A., \& Pargament, K. I. (2014). Sexuality and religion. In D. L. Tolman \& L. M. Diamond (Eds.), APA handbook of psychology and sexuality: Vol. 2: Contextual approaches (pp. 425-447). Washington, DC: American Psychological Association. http://dx.doi .org/10.1037/14194-013

Hernandez-Kane, K. M., \& Mahoney, A. (2018). Sex through a sacred lens: Longitudinal effects of sanctification of marital sexuality. Journal of Family Psychology, 32, 425-434. http://dx.doi.org/10.1037/ fam0000392

Higgins, J. A., Trussell, J., Moore, N. B., \& Davidson, J. K. (2010). Virginity lost, satisfaction gained? Physiological and psychological sexual satisfaction at heterosexual debut. Journal of Sex Research, 47, 384-394. http://dx.doi.org/10.1080/00224491003774792

Homan, K. J., \& Boyatzis, C. J. (2009). Body image in older adults: Links with religion and gender. Journal of Adult Development, 16, 230-238. http://dx.doi.org/10.1007/s10804-009-9069-8

Jacobson, H. L., Hall, M. E. L., \& Anderson, T. L. (2013). Theology and the body: Sanctification and bodily experiences. Psychology of Religion and Spirituality, 5, 41-50. http://dx.doi.org/10.1037/a0028042

Janda, L. H., \& Bazemore, S. D. (2011). The Revised Mosher Sex-Guilt Scale: Its psychometric properties and a proposed ten-item version. Journal of Sex Research, 48, 392-396. http://dx.doi.org/10.1080/ 00224499.2010.482216

Kleinplatz, P. J., Ménard, A. D., Paquet, M. P., Paradis, N., Campbell, M., Zuccarino, D., \& Mehak, L. (2009). The components of optimal sexuality: A portrait of "great sex". The Canadian Journal of Human Sexuality, 18(1/2), 1-13.

Kline, R. B. (2016). Principles and practice of structural equation modeling. New York, NY: Guilford Press.

Kusner, K. G., Mahoney, A., Pargament, K. I., \& DeMaris, A. (2014). Sanctification of marriage and spiritual intimacy predicting observed marital interactions across the transition to parenthood. Journal of Family Psychology, 28, 604-614. http://dx.doi.org/10.1037/a0036989

Lambert, N. M., \& Dollahite, D. C. (2008). The threefold cord: Marital commitment in religious couples. Journal of Family Issues, 29, 592 614. http://dx.doi.org/10.1177/0192513X07308395

Lauer, E. F. (1985). The holiness of marriage: Some new perspectives from recent sacramental theology. Studies in Formative Spirituality, 6, 215 226.

Lawrance, K., \& Byers, E. S. (1995). Sexual satisfaction in long-term heterosexual relationships: The interpersonal exchange model of sexual 
satisfaction. Personal Relationships, 2, 267-285. http://dx.doi.org/10 .1111/j.1475-6811.1995.tb00092.x

Leonhardt, N. D., \& Willoughby, B. J. (2017). Pornography, provocative sexual media, and their differing associations with multiple aspects of sexual satisfaction. Journal of Social and Personal Relationships. Advance online publication. http://dx.doi.org/10.1177/0265407517739162

Lewis, R. J., \& Janda, L. H. (1988). The relationship between adult sexual adjustment and childhood experiences regarding exposure to nudity, sleeping in the parental bed, and parental attitudes toward sexuality. Archives of Sexual Behavior, 17, 349-362. http://dx.doi.org/10.1007/ BF01541812

Ley, D. J. (2017, August). Overcoming religious sexual shame. Psychology Today. Retrieved from https://www.psychologytoday.com/blog/womenwho-stray/201708/overcoming-religious-sexual-shame

Little, T. D. (2013). Longitudinal structural equation modeling. New York, NY: Guilford Press.

Luquis, R. R., Brelsford, G. M., \& Rojas-Guyler, L. (2012). Religiosity, spirituality, sexual attitudes, and sexual behaviors among college students. Journal of Religion and Health, 51, 601-614. http://dx.doi.org/ 10.1007/s10943-011-9527-z

Mahoney, A. (2010). Religion in families 1999 to 2009: A relational spirituality framework. Journal of Marriage and the Family, 72, 805827. http://dx.doi.org/10.1111/j.1741-3737.2010.00732.x

Mahoney, A., Pargament, K. I., Tarakeshwar, N., \& Swank, A. B. (2001). Religion in the home in the 1980s and 1990s: A meta-analytic review and conceptual analysis of links between religion, marriage, and parenting. Journal of Family Psychology, 15, 559-596. http://dx.doi.org/10 $.1037 / 0893-3200.15 .4 .559$

Mark, K. P. K., Herbenick, D., Fortenberry, J. D., Sanders, S., \& Reece, M. (2014). A psychometric comparison of three scales and a single-item measure to assess sexual satisfaction. Journal of Sex Research, 51, 159-169. http://dx.doi.org/10.1080/00224499.2013.816261

McClelland, S. I. (2010). Intimate justice: A critical analysis of sexual satisfaction. Social and Personality Psychology Compass, 4, 663-680. http://dx.doi.org/10.1111/j.1751-9004.2010.00293.x

Mikulincer, M., \& Shaver, P. R. (2016). Attachment in adulthood, 2nd ed.: Structure, dynamics, and change. New York, NY: Guilford Press.

Miracle, T. S., Miracle, A. W., \& Baumeister, R. F. (2003). Human sexuality: Meeting your basic needs. Upper Saddle River, NJ: Prentice Hall.

Murray, K. M., Ciarrocchi, J. W., \& Murray-Swank, N. A. (2007). Spirituality, religiosity, shame and guilt as predictors of sexual attitudes and experiences. Journal of Psychology and Theology, 35, 222-234. http:// dx.doi.org/10.1177/009164710703500305

Murray-Swank, N. A., Pargament, K. I., \& Mahoney, A. (2005). At the crossroads of sexuality and spirituality: The sanctification of sex by college students. The International Journal for the Psychology of Religion, 15, 199-219. http://dx.doi.org/10.1207/s15327582ijpr1503_2

Muthén, L. K., \& Muthén, B. O. (1998-2012). MPlus user's guide (7th ed.). Los Angeles, CA: Author.

Nicolson, P. (1993). Deconstructing sexology: Understanding the pathologisation of female sexuality. Journal of Reproductive and Infant Psychology, 11, 191-201. http://dx.doi.org/10.1080/02646839308403218

Oliver, M. B., \& Hyde, J. S. (1993). Gender differences in sexuality: A meta-analysis. Psychological Bulletin, 114, 29-51. http://dx.doi.org/10 $.1037 / 0033-2909.114 .1 .29$

Olson, J. R., Marshall, J. P., Goddard, H. W., \& Schramm, D. G. (2015). Shared religious beliefs, prayer, and forgiveness as predictors of marital satisfaction. Family Relations, 64, 519-533. http://dx.doi.org/10.1111/ fare. 12129

Paolacci, G., Chandler, J., \& Ipeirotis, P. G. (2010). Running experiments on Amazon Mechanical Turk. Judgment and Decision Making, 5, 411419.

Pargament, K. I. (1997). The psychology of religion and coping: Theory, research, practice. New York, NY: Guilford Press.

Pargament, K. I., Oman, D., Pomerleau, J., \& Mahoney, A. (2017). Some contributions of a psychological approach to the study of the sacred. Religion, 47, 718-744. http://dx.doi.org/10.1080/0048721X.2017 .1333205

Petersen, J. L., \& Hyde, J. S. (2010). A meta-analytic review of research on gender differences in sexuality, 1993-2007. Psychological Bulletin, 136, 21-38. http://dx.doi.org/10.1037/a0017504

Peterson, J. A. (1964). Education for marriage (2nd ed.). New York, NY: Scribner.

Runkel, G. (1998). Sexual morality of Christianity. Journal of Sex \& Marital Therapy, 24, 103-122. http://dx.doi.org/10.1080/00926239 808404924

Schnarch, D. M. (1991). Constructing the sexual crucible: An integration of sexual and marital therapy. New York, NY: W. W. Norton Company.

Sigalow, E., \& Fox, N. S. (2014). Perpetuating stereotypes: A study of gender, family, and religious life in Jewish children's books. Journal for the Scientific Study of Religion, 53, 416-431. http://dx.doi.org/10.1111/ jssr.12112

Simonic, B., Mandelj, T. R., \& Novsak, R. (2013). Religious-related abuse in the family. Journal of Family Violence, 28, 339-349. http://dx.doi .org/10.1007/s10896-013-9508-y

Stotland, N. L. (2000). Tug-of-war: Domestic abuse and the misuse of religion. The American Journal of Psychiatry, 157, 696-702. http://dx .doi.org/10.1176/appi.ajp.157.5.696

Suri, S., \& Watts, D. J. (2011). Cooperation and contagion in web-based, networked public goods experiments. PLoS ONE, 8356(3), e16836. http://dx.doi.org/10.1371/journal.pone.0016836

Turner, T. E., Fox, N. J., \& Kiser, J. D. (2007). Uniting spirituality and sexual counseling: Semitic traditions. The Family Journal, 15, 294-297. http://dx.doi.org/10.1177/1066480707301615

Weyand, C., O'Laughlin, L., \& Bennett, P. (2013). Dimensions of religiousness that influence parenting. Psychology of Religion and Spirituality, 5, 182-191. http://dx.doi.org/10.1037/a0030627

Willoughby, B. J., \& James, S. L. (2017). The marriage paradox: Why emerging adults love marriage yet push it aside. New York, NY: Oxford University Press. http://dx.doi.org/10.1093/acprof:oso/9780190296650 001.0001

Woo, J. S. T., Brotto, L. A., \& Gorzalka, B. B. (2011). The role of sex guilt in the relationship between culture and women's sexual desire. Archives of Sexual Behavior, 40, 385-394. http://dx.doi.org/10.1007/s10508-0109609-0

Woo, J. S. T., Morshedian, N., Brotto, L. A., \& Gorzalka, B. B. (2012). Sex guilt mediates the relationship between religiosity and sexual desire in East Asian and Euro-Canadian college-aged women. Archives of Sexual Behavior, 41, 1485-1495. http://dx.doi.org/10.1007/s10508-012-9918-6

Young, M., Denny, G., Luquis, R. R., \& Young, T. (1998). Correlates of sexual satisfaction in marriage. The Canadian Journal of Human Sexuality, 7, 115-127.

Received February 21, 2018

Revision received October 23, 2018

Accepted November 8, 2018 